\title{
Chemical Reduction of Nitrate Using Nanoscale Bimetallic Iron/Copper Particles
}

\author{
Jifeng Guo*, Ping Guo, Miaomiao Yu, Zexin Sun, Pengtao Li, \\ Tong Yang, Jing Liu, Liyuan Zhang \\ School of Environmental Science and Engineering, Key Laboratory of Subsurface Hydrology \\ and Ecology in Arid Areas of Education Ministry, Chang'an University, Xi'an, China
}

\author{
Received: 7 August 2017 \\ Accepted: 9 October 2017
}

\begin{abstract}
Nanoscale zero-valent iron (NZVI) as an effective material has been applied to reduce nitrate. Yet NZVI has defects of aggregation and oxidation. To overcome these disadvantages, nanoscale bimetallic iron/copper particles were introduced to reduce nitrate in this work. In this paper, nanoscale bimetallic $\mathrm{Fe} / \mathrm{Cu}$ particles were prepared by the liquid phase chemical reduction method; the particles were characterized by scanning electron microscopy (SEM) and x-ray diffraction (XRD). The effect of prepared particles was evaluated by reducing synthetic nitrate wastewater, and batch experiments were conducted to investigate the effect of initial nitrate concentration and various $\mathrm{Cu}$ loading on nitrate reduction by nanoscale bimetallic $\mathrm{Fe} / \mathrm{Cu}$ particles. The results indicated that nitrate could be completely removed in 20 min reaction by nanoscale bimetallic $\mathrm{Fe} / \mathrm{Cu}$ particles when $\mathrm{Cu}$ loading was $5 \%$ and initial nitrate concentration was $80 \mathrm{mg} / \mathrm{L}$. As a result, the nitrate in wastewater was converted into ammonium and nitrogen gas, with nitrite as an intermediate by-product.
\end{abstract}

Keywords: nanoscale bimetallic iron/copper particles, chemical reduction, nitrate wastewater

\section{Introduction}

In recent years, human industrial and agricultural production such as farmland fertilization, sewage irrigation, and large amounts of contained nitrogen domestic sewage and industrial wastewater emissions have made nitrate pollution increasingly severe in water [1-2]. The content of nitrate and nitrite exceeded the standard and not only deteriorated water quality but also was a severe hazard to human and animal health. In the human body, nitrate can be reduced to nitrite,

*e-mail: guojifeng@chd.edu.cn which could react with hemoglobin in blood to form methemoglobin, preventing it from transporting oxygen to body tissues. It poisoned people by depriving them of oxygen, leading to methemoglobinemia, or "blue baby" syndrome. Moreover, nitrite worked with secondary amines form nitrosamines both inside and outside the human body. Nitrosamines were carcinogenic, teratogenic, mutagenic substances and harmful to human health when they reached a certain dose in the human body [3]. Therefore, it was significant to study how to effectively remove nitrate in water.

Nitrate in water had high solubility and fine stability, which was difficult to form co-precipitation or adsorption. Currently, methods of removing nitrate 
include physicochemical, such as ion exchange (IE) [4], reverse osmosis (RO) [5], electro-dialysis (ED) [6]), biological denitrification (BD) [7-8], and chemical reduction (CR) [9] etc. These methods could remove nitrate to different extents. However, they all had definite disadvantages. In fact, physicochemical methods failed to remove nitrate completely, only to be transferred or concentrated [10]. Meanwhile, they would produce a large number of high concentration regeneration waste fluids and needed further treating, therefore the cost was high. Biological denitrification was characterized by a low biochemical reaction rate and complex operating conditions. Chemical reduction methods referred to use certain chemical reductants to remove nitrate, metal reductants including iron $(\mathrm{Fe})$, aluminum ( $\mathrm{Al})$, and zinc ( $\mathrm{Zn})$ were applied extensively at present, and the iron powder was closely studied. Due to certain restrictions of iron powder in treatment effectiveness, nanoscale zero-valent iron has been rapidly developed.

NZVI has been extensively applied to reduce nitrate [11-13] due to its advantages of a large specific surface area and high reactivity. However, studies have indicated that NZVI had a tendency to agglomerate and oxidize, which led to decreased reactivity and limited its wide application [14]. Several carriers such as bentonite [15], silica [16], activated carbon [17], and chitosan [18] have been introduced on the surface of NZVI was an approach to improve the reactivity of NZVI. These composites had great improvement on contaminant removal, and the agglomeration of NZVI decreased. These indicated that the nitrate removal rate was enhanced when the carriers were introduced.
Coating NZVI by using another metal catalyst such as $\mathrm{Pt}, \mathrm{Pd}$, and $\mathrm{Cu}$ (named nanoscale bimetallic particles) was another effective and novel way to improve the reactivity of NZVI. It had been reported that nanoscale bimetallic particles were applied to degrade chlorinated hydrocarbons [19-20]. However, studies about nanoscale iron bimetallic particles for reducing nitrate wastewater have rarely been systematically reported.

Among the surface modifier metals for NZVI, $\mathrm{Cu}$ was known as a mild catalyst. In this study, metal $\mathrm{Cu}$ was introduced as a catalyst of NZVI. Nanoscale bimetallic iron/copper $(\mathrm{Fe} / \mathrm{Cu})$ particles (NZVI coating $\mathrm{Cu}$ as a catalyst) were prepared by the step liquid phase chemical reduction method. Batch experiments were conducted to reduce nitrate by the prepared nanoscale bimetallic $\mathrm{Fe} / \mathrm{Cu}$ particles. The products of the reaction were also analyzed. This would provide more theoretical basis for the reduction of nitrite by nano-iron bimetallic particles. Meanwhile, this also provided an effective method for nitrate removal.

\section{Material and Methods}

\section{Materials}

Main chemical reagents used in the experiments included ferrous sulfate heptahydrate (CAS number: 7782-63-0, $\mathrm{FeSO}_{4} \cdot 7 \mathrm{H}_{2} \mathrm{O}$, Guangdong Guanghua Sci-Tech Co. Ltd, China), potassium borohydride (CAS number: 13762-51-1, $\mathrm{KBH}_{4}$ Guangdong Guanghua Chemical Factory Co. Ltd, China), absolute ethyl alcohol (CAS number: 64-17-5, Xi'an Chemical Reagent Factory,

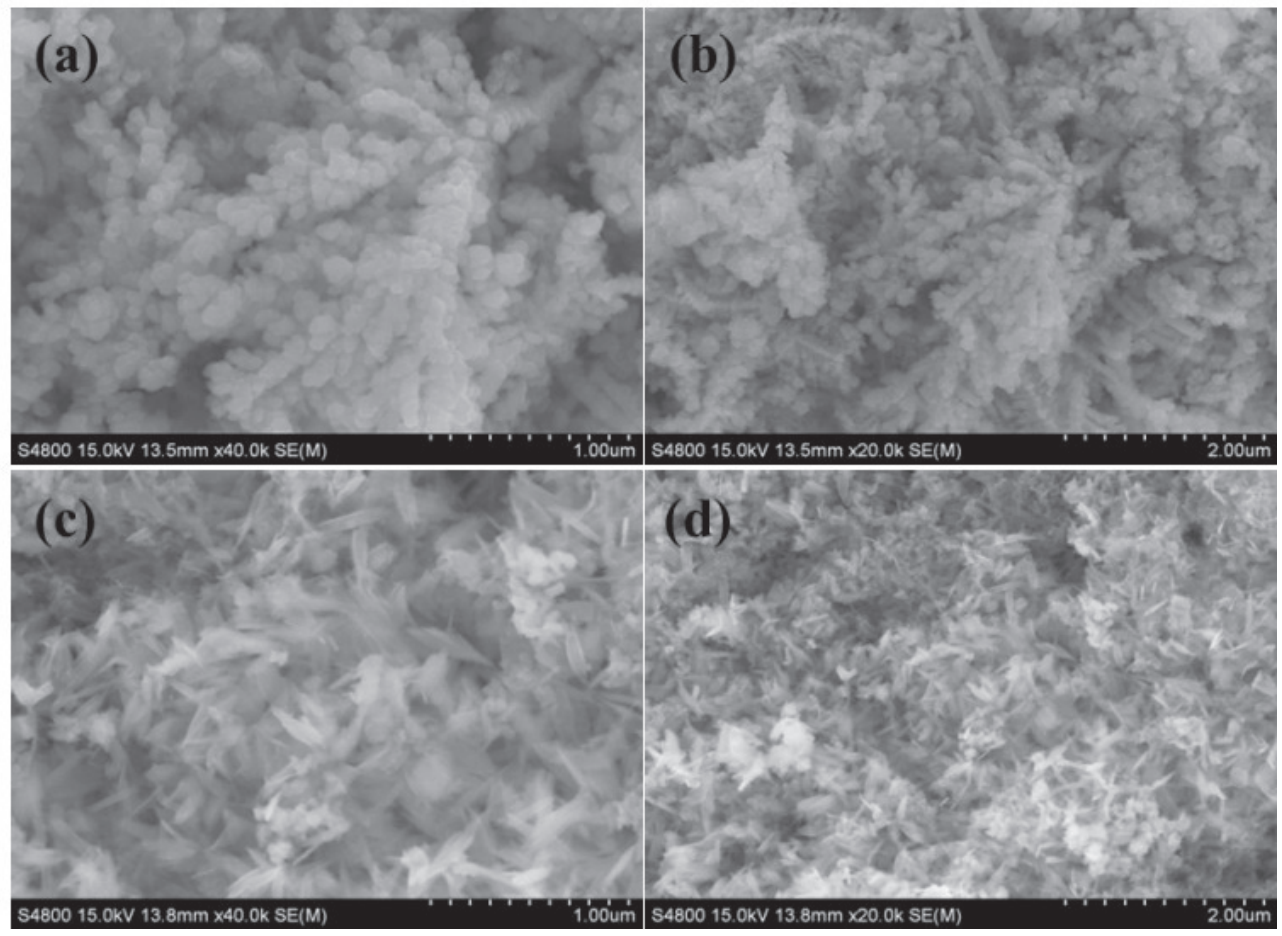

Fig. 1. SEM images of two bimetallic $\mathrm{Fe} / \mathrm{Cu}$ particles. 
China), polyethylene glycol 4000 (CAS number: 2532268-3, PEG-4000, Guangdong Guanghua Chemical Factory Co. Ltd, China), sodium nitrate (CAS number: 7631-99-4, $\mathrm{NaNO}_{3}$, Guangdong Guanghua Sci-Tech Co. Ltd, China), and copper sulfate pentahydrate (CAS number: 7758-99-8, $\mathrm{CuSO}_{4} \cdot 5 \mathrm{H}_{2} \mathrm{O}, \quad \mathrm{Xi}$ 'an Chemical Reagent Factory, China) - all of which were of analytical grade. Iron powder was purchased from Tianjin University chemical reagent factory. The experimental water source was simulated nitrate wastewater prepared using analytically pure potassium nitrate.

\section{Methodology of Bimetallic Fe/Cu Particles Preparation}

Ordinary bimetallic $\mathrm{Fe} / \mathrm{Cu}$ and nanoscale bimetallic $\mathrm{Fe} / \mathrm{Cu}$ particles were prepared by liquid phase chemical reduction method [21-22].

Ordinary bimetallic $\mathrm{Fe} / \mathrm{Cu}$ particles: $0.2 \mathrm{~g}$ iron powder was added into a beaker with $100 \mathrm{~mL}$ $\mathrm{CuSO}_{4} \cdot 5 \mathrm{H}_{2} \mathrm{O}$ solution $(0.00156 \mathrm{~mol} / \mathrm{L})$. The solution was stirred to complete reaction under nitrogen atmosphere. In this way, ordinary bimetallic $\mathrm{Fe} / \mathrm{Cu}$ particles were prepared. The prepared materials were filtered and stored in deoxidized deionized water (injected with nitrogen).

Nano Fe/Cu particles: 1.0 g FeSO $\cdot 7 \mathrm{H}_{2} \mathrm{O}$ was added into $500 \mathrm{~mL}$ beaker with $100 \mathrm{~mL}$ ethanol-water solution (ethanol: water $=2: 5$ ), the concentration of ferrous sulfate was $0.036 \mathrm{~mol} / \mathrm{L} ; 0.5 \mathrm{~g}$ PEG-4000 was also added. $100 \mathrm{~mL} 0.108 \mathrm{~mol} / \mathrm{L}\left(\mathrm{KBH}_{4}: \mathrm{Fe}=3: 1\right) \mathrm{KBH}_{4}$ solution were added into the above solution dropwise and stirred constantly. After $\mathrm{KBH}_{4}$ solution dropped completely, through nitrogen stirring for more than $5 \mathrm{~min}$, so that the reaction was complete. Nanoscale iron particles were obtained as follows:

$$
\mathrm{Fe}\left(\mathrm{H}_{2} \mathrm{O}\right)_{6}^{2+}+2 \mathrm{BH}_{4}^{-} \rightarrow \mathrm{Fe}^{0}+2 \mathrm{~B}(\mathrm{OH})_{3}+7 \mathrm{H}_{2} \uparrow
$$

The products were washed with absolute ethyl alcohol and then washed with deoxidized deionized water several times. The whole process was carried out under nitrogen atmosphere.

The freshly prepared nanoscale iron particles were added to $50 \mathrm{~mL}$ deoxidized deionized water to form a suspension and ultrasonic dispersion for 10 minutes. $100 \mathrm{~mL} \mathrm{CuSO} \cdot 5 \mathrm{H}_{2} \mathrm{O}$ solution was slowly added to the suspension of nanoscale iron and stirred under nitrogen protection. After complete addition, the reaction was injected with nitrogen continually for $3 \mathrm{~min}$. Nano $\mathrm{Fe} / \mathrm{Cu}$ particles (5\% $\mathrm{Cu}$ loading) were obtained according to the following reaction [23]:

$$
\mathrm{Fe} 0+\mathrm{Cu}^{2+} \rightarrow \mathrm{Fe}^{2+}+\mathrm{Cu}^{0}
$$

The particles were filtered and washed with absolute ethyl alcohol and then washed with deoxidized deionized water several times.

\section{Analysis Methods}

The morphology of particles was characterized by SEM (S-4800, Hitachi, Japan) with $15.0 \mathrm{kV}$ operating voltages. The crystal phase was measured by x-ray diffraction (D8ADVANCE, Brooke AXS Company, Germany), with $\mathrm{Cu}$ target $\mathrm{K} \alpha$ radiation, working voltage was $40 \mathrm{kV}$, and scan area was $30 \sim 60^{\circ}$. Nitrate nitrogen was determined by ultraviolet spectrophotometry, nitrite nitrogen was measured by $\mathrm{N}$-(1-naphthyl)-ethylene diamine spectrophotometry, and determination of ammonia nitrogen by nessler's reagent spectrophotometry.

\section{Batch Nitrate Reduction Experiments}

Batch nitrate reduction experiments were conducted in a $250 \mathrm{~mL}$ conical flask with $150 \mathrm{~mL}$ certain concentration simulated nitrate wastewater. Nano $\mathrm{Fe} / \mathrm{Cu}$ particles dosage was $1.4 \mathrm{~g} / \mathrm{L}$. To ensure anaerobic conditions, wastewater was injected with nitrogen and flasks were sealed. The reaction was carried out in the condition of neutral $\mathrm{pH}$ and vibrated with a SHACT chilled water bath thermostat oscillator at $20^{\circ} \mathrm{C}$ at $150 \mathrm{rpm}$. Samples were periodically taken, filtered, and measured to investigate iron content.

\section{Results and Discussion}

\section{SEM Analysis}

Two prepared kinds of bimetallic $\mathrm{Fe} / \mathrm{Cu}$ particles were adequately dried in vacuum. The morphologies were characterized by SEM. Figs 1a-b) showed SEM images of ordinary bimetallic $\mathrm{Fe} / \mathrm{Cu}$ particles in which iron particles were white and granular, and dendritic copper was interspersed with large amounts of iron particles. The particles were well dispersed and the specific surface area of particles increased due to the joining of copper. Figs 1c-d) were the SEM image of nano $\mathrm{Fe} / \mathrm{Cu}$ particles. It can be seen clearly that nano $\mathrm{Fe} / \mathrm{Cu}$ particles were like chaotic feathers; the sample size was less than $100 \mathrm{~nm}$. The dispersity of NZVI increased prominently when the $\mathrm{Cu}$ catalyst was introduced. The sample surface was uneven, which was conducive to increasing the surface area [24]. There were many channels and voids in the surface.

\section{XRD Analysis}

Fig. 2 was the XRD pattern of prepared nanoscale bimetallic $\mathrm{Fe} / \mathrm{Cu}$ particles. Nano $\mathrm{Fe} / \mathrm{Cu}$ particles had a sharp $\alpha$-Fe diffraction peak at $2 \theta=44.67^{\circ}$, and the corresponding crystal plane was (110), which $\backslash$ coincided with the standard PDF2 card. There were two $\mathrm{Cu}$ diffraction peaks at $2 \theta=43.39^{\circ}$ and $2 \theta=50.48^{\circ}$ in the $2 \theta$ angle range of $30^{\circ}$ to $60^{\circ}$. In addition, iron oxide was not observed. 


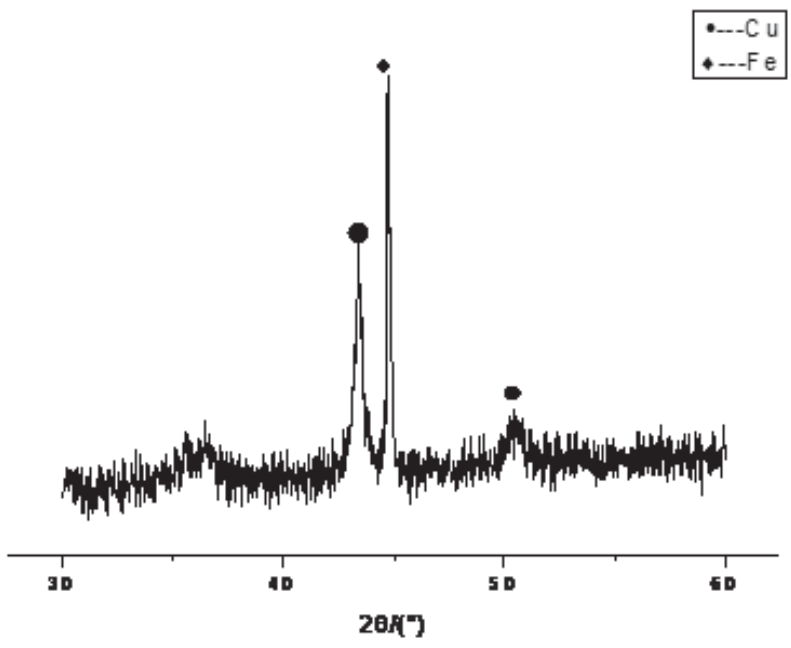

Fig. 2. XRD pattern of prepared nanoscale bimetallic $\mathrm{Fe} / \mathrm{Cu}$ particles.

\section{Nitrate Reduction by Two Bimetallic $\mathrm{Fe} / \mathrm{Cu}$ Particles}

The nitrate reduction abilities of two bimetallic $\mathrm{Fe} / \mathrm{Cu}$ particles were compared in Fig. 3 , where $\mathrm{C} / \mathrm{C}_{0}$ was the ratio of exploratory ion concentration to initial nitrate concentration in the solution. The results showed that nitrate removal rate was $24.8 \%$ at $20 \mathrm{~min}$ and only $30 \%$ when the reaction was complete by ordinary bimetallic $\mathrm{Fe} / \mathrm{Cu}$ particles, while nitrate removalrate was $91.9 \%$ at $20 \mathrm{~min}$ and nearly $100 \%$ at $40 \mathrm{~min}$ by nano $\mathrm{Fe} / \mathrm{Cu}$ particles under the same conditions. This was because the active mechanism for removing nitrate by nanoscale bimetallic $\mathrm{Fe} / \mathrm{Cu}$ particles was utilizing its large specific surface area and high reactivity; the nitrate removal rate could reach nearly $100 \%$ in a short time. As can be seen in Figs 1(c-d), there were many channels and voids in the surface of nanoscale bimetallic $\mathrm{Fe} / \mathrm{Cu}$ particles, which provided more adsorption sites and active sites for the reaction. This greatly enhanced

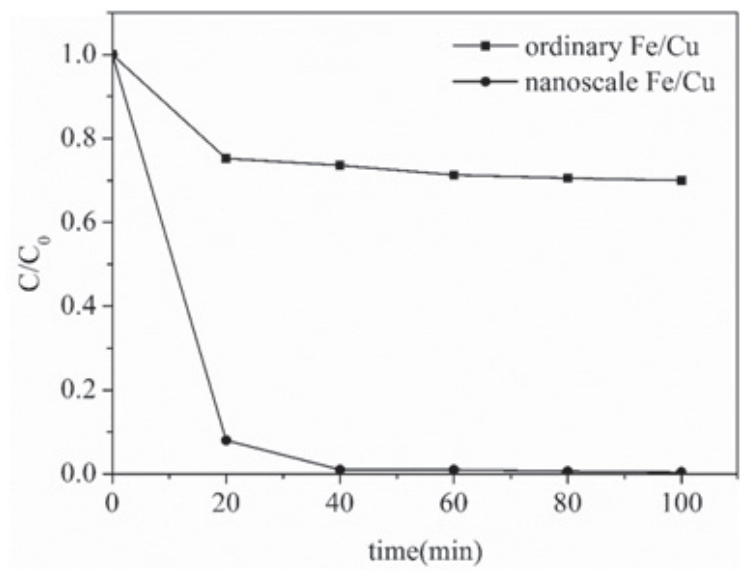

Fig. 3. Nitrate reduction ability of two bimetallic $\mathrm{Fe} / \mathrm{Cu}$ particles (nitrate nitrogen concentration $=100 \mathrm{mg} / \mathrm{L}$ ). the activity of nanoscale bimetallic $\mathrm{Fe} / \mathrm{Cu}$ particles.

\section{Effect on Nitrate Reduction by Nano $\mathrm{Fe} / \mathrm{Cu}$ Particles}

\section{Effect of Initial Nitrate Concentration}

Effects of initial nitrate nitrogen concentration on nitrate reduction by nano $\mathrm{Fe} / \mathrm{Cu}$ particles are shown in Figs 4a-b), which shows that the initial nitrate nitrogen concentrations were $40,80,100$, and $120 \mathrm{mg} / \mathrm{L}$, respectively, and when the reaction time was $5 \mathrm{~min}$, nitrate removal rates reached $80.6 \%, 71.2 \%, 70.2 \%$, and $66 \%$, respectively. When the nitrate nitrogen concentration was not higher than $80 \mathrm{mg} / \mathrm{L}$, the nitrate removal rate was close to $100 \%$ at $20 \mathrm{~min}$, while nitrate nitrogen concentration was $120 \mathrm{mg} / \mathrm{L}$; nitrate removal rate was $89.6 \%$, which indicated that the nitrate removal rate decreased with the increase of initial nitrate concentration. Nitrate reduction reaction needed to be adsorbed to the surface of nanoscale bimetallic $\mathrm{Fe} / \mathrm{Cu}$ particles first, and then conducted redox reactions in reactive sites of the surface [25]. The increase of nitrate content occupied more reactive sites, resulting in a saturation effect; therefore, nitrate removal rate was slower.

\section{Effect of Various $\mathrm{Cu}$ Loading}

Liou [26] showed that $\mathrm{Cu}$ loading could markedly affect nitrate removal rates. Effects of various $\mathrm{Cu}$ loading on nitrate reduction are shown in Fig. 5, which clearly shows that nano $\mathrm{Fe} / \mathrm{Cu}$ particles with $5 \% \mathrm{Cu}$ loading had the best nitrate removal efficiency, with the nitrate removal rate reaching $100 \%$ within $20 \mathrm{~min}$. While $\mathrm{Cu}$ loading was $1 \%$ and $20 \%$, the removal rate was only $78 \%$ and $60 \%$, respectively. The reactivity increased with the rise of $\mathrm{Cu}$ loading up to $5 \%$ and a further rise of $\mathrm{Cu}$ loading failed to increase reactivity. The loading was too small or too large; the reactivity of nanoscale bimetallic $\mathrm{Fe} / \mathrm{Cu}$ particles would be decreased. This was because the small loading was not enough to cause surface property change of nanoscale iron particles, and excessive loading would cover the surface of nanoscale iron particles, thus failing to fully contact with the nitrate, and removal rate decreased.

\section{Nitrate Reduction Product Analysis}

Product analysis and total nitrogen balance of nitrate reduction by nanoscale bimetallic $\mathrm{Fe} / \mathrm{Cu}$ particles are shows in Fig. 6. With the progress of the reaction, the nitrate nitrogen concentration decreased persistently and removal rate was almost $100 \%$ at $40 \mathrm{~min}$. During the reaction, $22.4 \%$ nitrate was reduced to nitrite, which was as intermediate by-product remained in the solution. Nitrite was converted to ammonia nitrogen further with the reaction continued and $7.7 \%$ nitrite remained in solution in the final. Since the amount of nitrite was 

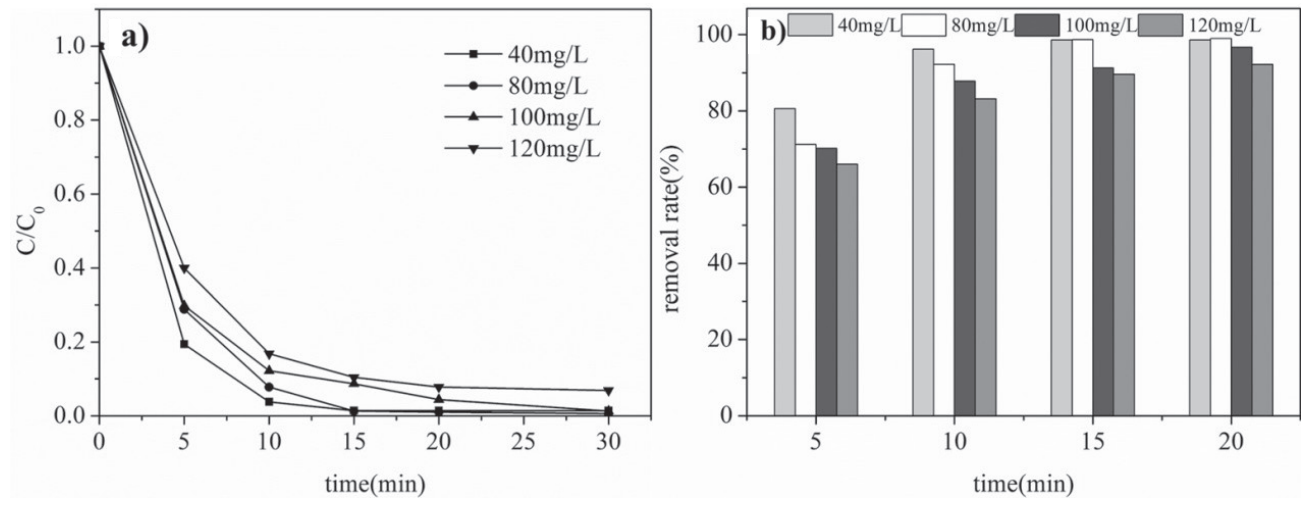

Fig. 4. Effect of different initial nitrate concentrations on nitrate removal rate $(\mathrm{Cu}$ loading $=5 \%)$.

small, it could be reduced further. So the amount of nitrite was not controlled deliberately in the experiment. $86.1 \%$ of the reaction final product was ammonia nitrogen. The total nitrogen (nitrate nitrogen, nitrite nitrogen, and ammonia nitrogen) showed a tendency of first decreasing and then increasing, and the total nitrogen content decreased 5\%. During the reaction, the $\mathrm{pH}$ increased from 7.24 to 10 or so. Here, the reduced total nitrogen was in the form of nitrogen gas $\left(\mathrm{N}_{2}\right)$ or ammonium. In addition, when nitrate nitrogen was removed quickly, there was still the presence of nitrite nitrogen, which indicated fully that the reaction process was a continuous stepwise reaction, namely $\mathrm{NO}_{3}^{-}-\mathrm{N} \rightarrow \mathrm{NO}_{2}^{-}-\mathrm{N} \rightarrow \mathrm{NH}_{4}^{+}-\mathrm{N}$. The conversion from nitrate to nitrite was faster and from nitrite to ammonia was relatively slow.

Iron and copper could be converted into ions $\left(\mathrm{Fe}^{2+} / \mathrm{Fe}^{3+}\right.$ and $\left.\mathrm{Cu}^{2+}\right)$ during the reaction. In this experiment, the $\mathrm{pH}$ value increased to 10 or so after reaction, $\mathrm{Fe}^{2+} / \mathrm{Fe}^{3+}$ would precipitated in alkaline condition. Nanoscale bimetallic $\mathrm{Fe} / \mathrm{Cu}$ particles dosage was $1.4 \mathrm{~g} / \mathrm{L}$ and the $\mathrm{Cu}$ loading was $5 \%$ in the experiment. There was only $0.01 \mathrm{~g} \mathrm{Cu}$ in $150 \mathrm{~mL}$ solution. By continuing to increase the $\mathrm{pH}$ value of the

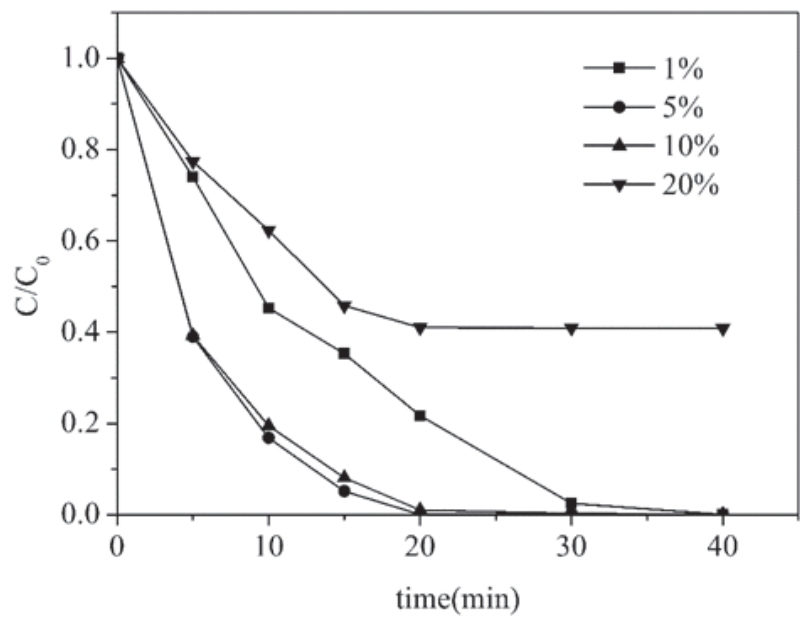

Fig. 5. Effect of various $\mathrm{Cu}$ loadings on nitrate reduction (nitrate nitrogen concentration $=80 \mathrm{mg} / \mathrm{L}$ ) solution, the purpose of further precipitation of $\mathrm{Cu}$ ion will be achieved.

\section{Conclusions}

In this study, the prepared nanoscale bimetallic $\mathrm{Fe} / \mathrm{Cu}$ particles decreased the aggregation of NZVI, and dispersity of NZVI increased prominently when catalyst $\mathrm{Cu}$ was introduced. Iron oxide was not observed in the pattern of XRD. It can be concluded that the join of the catalyst $\mathrm{Cu}$ overcame the shortcomings of aggregation and oxidation of NZVI. The results indicated that nanoscale bimetallic $\mathrm{Fe} / \mathrm{Cu}$ could effectively reduce nitrate. Nitrate could be completely removed in $20 \mathrm{~min}$ reaction by nanoscale bimetallic $\mathrm{Fe} / \mathrm{Cu}$ particles when $\mathrm{Cu}$ loading was $5 \%$ and initial nitrate concentration was under $80 \mathrm{mg} / \mathrm{L}$. As a result, the nitrate in wastewater was converted into ammonium and nitrogen gas, with nitrite as an intermediate byproduct. This would provide more theoretical basis for the reduction of nitrite by nano-iron bimetallic particles. Meanwhile, this also provided an effective method for nitrate removal.

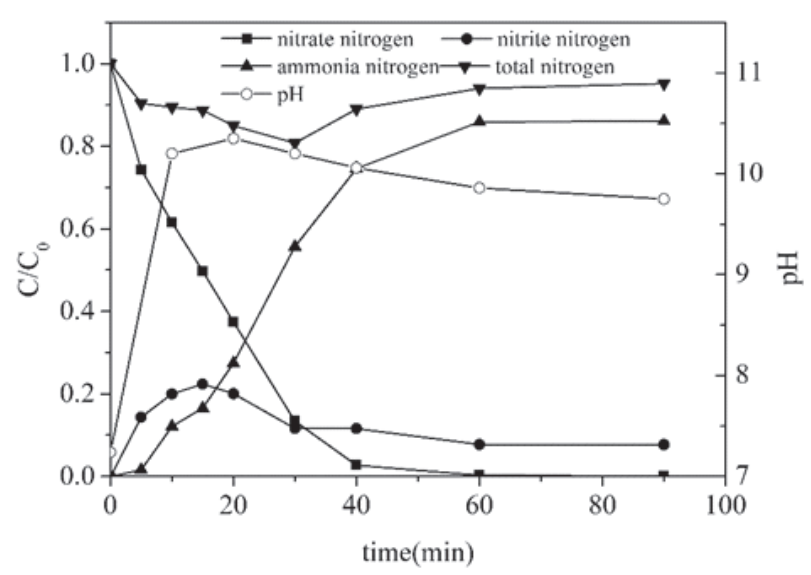

Fig. 6. Product analysis and total nitrogen balance of nitrate reduction by nanoscale bimetallic $\mathrm{Fe} / \mathrm{Cu}$ particles (nitrate nitrogen concentration $=80 \mathrm{mg} / \mathrm{L}, \mathrm{Cu}$ loading $=5 \%$ ). 


\section{Acknowledgements}

This study was financially supported by the Special Fund for Basic Scientific Research of Central Colleges, Chang'an University (310829172002, 310829161005), Chang'an University's Students Innovation Program (201710710098), the National Natural Science Foundation of China (21407012), and the Special Transport Technological Fund for Western China (2012318361110).

\section{References}

1. SIQINGXIA, FOHUAZHONG, YANHAOZHANG, HAIXIANGLI, XINYANG. Bio-reduction of nitrate from groundwater using ahydrogen-based membrane biofilm reactor. Journal of Environmental Sciences. 22 (2), 257, 2010.

2. XIONG Z., ZHAO D., PAN G. Rapid and controlled transformation of nitrate in water and brine by stabilized iron nanoparticles. Journal of Nanoparticle Research. 11, 807, 2009.

3. GHAFARI S., HASAN M., AROUA M.K. Bioelectrochemical removal of nitrate from water and wastewater--a review. Bioresource Technology. 99, 3965, 2008.

4. DZIUBEK A.M., MAĆKIEWICZ J. Removal of nitrates from water by selective ion exchange. Environment Protection Engineering. 35 (1), 171, 2009.

5. RAZI EPSZTEIN, ODED NIR, ORI LAHAV, MICHAL GREEN. Selective nitrate removal from groundwater using a hybrid nanofiltration - reverse osmosis filtration scheme. Chemical Engineering Journal. 279, 372, 2015.

6. FATMA GUESMI, SOUMAYA HARBI, SAMEH AMOURI, ISLEM LOUATI, CHIRAZ HANNACHI, AND BÉCHIR HAMROUNI. Application of Response Surface Methodology to Optimize Nitrate Removal from Water by Electrodialysis. Chemistry Letters. 45(12), 1369, 2016.

7. SRINU NAIK S., PYDI SETTY Y. Optimization of parameters using response surface methodologyand genetic algorithm for biological denitrification of wastewater. Interational Journal of Environmental Science and Technology. 11 (3), 823, 2013.

8. ABBAS REZAEEHATAM, GODINISAID, DEHESTANIAHMAD, REZA YAZDANBAKHSHGHOLAMREZA, MOSAVIANOSHIRAVAN KAZEMNEJAD Biological denitrification by Pseudomonas stutzeri immobilizedon microbial cellulose. World Journal of Microbiology\&Biotechnology. 24 (11), 2397, 2008.

9. HU S., ZHANG C., YAO H. Intensify chemical reduction to remove nitrate from groundwater via internal microelectrolysis existing in nano-zero valent iron/ granular activated carbon composite. Desalination \& Water Treatment. 57 (30), 14158, 2016.

10. PARK J.Y., BYUN H.J., CHOI W.H. Cement paste column for simultaneous removal of fluoride, phosphate, and nitrate in acidic wastewater. Chemosphere. 70 (8), 1429, 2008.

11. YIMING S.U., ADEYEMI S. ADELEYE, YUXIONG HUANG, XIAOYA SUN, CHAOMENG DAI, XUEFEI ZHOU, YALEI ZHANG, ARTURO A. KELLER.
Simultaneous removal of cadmium and nitrate in aqueous media by nanoscalezerovalent iron (nZVI) and Au doped nZVI particles. Water Research. 63, 102, 2014.

12. ZHANG J., HAO Z., ZHANG Z., YANG Y., XU X. Kinetics of nitrate reductive denitrification by nanoscale zero-valent iron. Process Safety \& Environmental Protection. 88, 439, 2010.

13. ZIAJAHROMI S., KHANIZADEH M., KHIADANI M., ZAND A.D., MEHRDAD M. Experimental evaluation of nitrate reduction from water using synthesis nanoscale zero-valent iron (NZVI) under aerobic conditions. Middle East Journal of Scientific Research. 16 (2), 205, 2013.

14. PHENRAT T., SALEH N., SIRK K., TILTON R.D., LOWRY G.V. Aggregation and sedimentation of aqueous nanoscalezerovalent iron dispersions. Environmental Science \& Technology. 41, 284, 2007.

15. SHI L.N., ZHANG X., CHEN Z.L. Removal of Chromium (VI) from wastewater using bentonite-supported nanoscale zero-valent iron. Water research. 45, 886, 2011.

16. ZHAN J., ZHENG T., PIRINGER G., DAY C., MCPHERSON G.L., LU Y., PAPADOPOULOS K., JOHN V.T. Transport characteristics of nanoscale functional zerovalent iron/silica composites for in situ remediation of trichloroethylene. Environmental Science \& Technology. 42, 8871, 2008.

17. TSENG H.H., SU J.G., LIANG C. Synthesis of granular activated carbon/zero valent iron composites for simultaneous adsorption/dechlorination of trichloroethylene. Journal of hazardous materials. 192, 500, 2011.

18. LIU T., LIN Z., SUN D., XIN T. Entrapment of nanoscale zero-valent iron in chitosan beads for hexavalent chromium removal from wastewater. Journal of hazardous materials. 184, 724, 2010

19. ZHOU HONGYI, XU XINHUA, WANG DAHUI. Catalytic Dechlorination and Kinetics of o-Dichlorobenzene by $\mathrm{Pd} /$ Fe. Chinese Journal of Chemical Engineering. 12 (4), 505, 2004.

20. FENG H.E., DONGYE ZHAO. Preparation and Characterization of a New Class of Starch-Stabilized Bimetallic Nanoparticles for Degradation of Chlorinated Hydrocarbons in Water. Environmental Science \& Technology. 39 (9), 3314, 2005.

21. WANG W., JIN Z.H., LI T.L., ZHANG H., GAO S. Preparation of spherical iron nanoclusters in ethanol-water solution for nitrate removal. Chemosphere. 65, 1396, 2006

22. ZHANG W.X. Nanoscale Iron Particles for Environmental Remediation: An Overview. Journal of Nanoparticle Research. 5, 323, 2003.

23. HOSSEINI S.M., ATAIE-ASHTIANI B., KHOLGHI M. Nitrate reduction by nano-Fe/Cu particles in packed column. Desalination. 276, 214, 2011.

24. XU XINHUA, WEI JIANJUN, WANGDAHUI. Studies on dechlorination of chlorophenols with $\mathrm{Pd} / \mathrm{Fe}$ and nanoscale $\mathrm{Pd} /$ Fe.China Environmental Science. 24 (1), 76, 2004.

25. ZHANG Y., LI Y., LI J., HU L., ZHENG X. Enhanced removal of nitrate by a novel composite: Nanoscale zero valent iron supported on pillared clay. Chemical Engineering Journal. 171, 526, 2011.

26. LIOU Y.H., LO S.L., LIN C.J., KUAN W.H., WENG S.C. Chemical reduction of an unbuffered nitrate solution using catalyzed and uncatalyzednanoscale iron particles. Journal of hazardous materials. 127, 102, 2005. 